Not a word of self praise; not a syllable of self depreciation; a simple proud humility in the acknowledgment of pleasure that his printed thoughts were remembered by a stranger.

I had outstaid the moments to which I was pledged to limit my visit. I rose to go, and our hands met in friendly farewell. "Stay," he exclaimed. "Do you care for this?" and he wrote with firm stroke the following:

\title{
Walt Whitman
}

April 22 '90

Then he added his message of regard to "the boys in New York," and we parted.

At the foot of the stairs stood the two faithful watchers. The dog bounded up the steps; with the woman I stopped to chat a moment. "You did right," she smiled sadly, "not to bother him with questions. He is over 70 now, and the years bring their weight."

Outside the sun shone, the birds sang, and the boys played. Within the doors sat the uncomplaining patriarch who has chanted the might and glory of America, and yet, strange to say, has gained greater applause and more practical sympathy beyond the seas than from the land he has celebrated.

Whitman does not explicitly mention this visit to Horace Traubel in With Walt Whitman in Camden, but on the evening of April 22, 1890, he does refer to the "easy employment of a congenial nature" that seemed to be the main purpose of the correspondent's visit. Whitman tells Traubel:

Today I had an application from the American Press Association. What for? A specialty? Oh no! - anything, I suppose-prose or verse. $\mathrm{O}$ the mutations of years! Only a few years ago - five only-I waited for just such orders - wondered, and was willing, able, still with a modicum of strength: but no message came-the world did not want me. Now - hardly half a decade after, comes a multitude: comes cry and cry-after my power to respond is gone: after I am wrecked, stranded, left but to look for the end - or near end! And yet there is a sense of satisfaction in this. . .." (WWC 6:373-374).

In his Daybook for April 22, 1890, Whitman noted that he was receiving "quite a number of offers f'm publishers, magazine editors, \& heads of newspaper syndicates these times" ( $D B N$ 2:551). So, even though Whitman had been "too ill" to see his friend John Forney's daughter, who stopped by that day for a visit (WWC 6:374), he clearly had signaled Mary Davis to allow the Tribune correspondent to come up to his room so that he could collect another welcome offer to publish his work.

The University of Iowa

ED FoLSOM

\section{HUNEKER'S “A VISIT TO WALT WHITMAN”}

I have dealt previously with James Gibbons Huneker's connection with and criticism of Walt Whitman. ${ }^{1}$ Here I want to focus on Huneker's most extensive discussion of Whitman, his essay "A Visit to Walt Whitman," which was briefly foreshadowed in his "Raconteur" column in the Musical Courier 37 (July 12, 1898), 23-24; elaborated to essay length in his "The Seven Arts" column in Puck 76 (November 21, 1914), 8, 20; and reprinted in his book Ivory Apes and Peacocks (New York: Charles Scribner's Sons, 1915), 22-31 (hereafter $I A P$ ). 
This essay, about which the conservative literary critic Fred Lewis Pattee wrote "I know of no such penetrating estimate of Walt Whitman as [Huneker] has given in a single brief essay," ${ }^{2}$ is also significant as being the first by a professional American literary critic in which Whitman is explicitly described as a homosexual and parts of Leaves of Grass as "the bible of the third sex." But as far as I am aware the piece has been overlooked in Whitman criticism, ${ }^{4}$ and, despite its historical importance and acuity, its factual errors have gone uncorrected.

A comparison of the "Raconteur" remarks and the Puck version of the essay with the reprinted one reveals, apart from a few minor verbal changes, several substantial additions or deletions. ${ }^{5}$ In the "Raconteur" column Huneker wrote that Whitman gave him an autographed copy of the 1867 edition of Leaves and the "five dollars I gave in return was handed over to some asylum for queer people or hospital for queer diseases, near Camden." In Puck and $I A P$ he thought the amount paid for the book was two dollars, and he deleted the "queer" phrase. In Puck Huneker remarked that when Lincoln first saw Whitman he said "Well, he looks like a man!," but in IAP Huneker italicizes the word "looks" (20), perhaps implying that Lincoln had heard rumors about Whitman's sexuality. In Puck Huneker stated that Secretary Harlan had dismissed Whitman "because of an offense against morals" (8); in IAP the last four words are omitted and replaced by the one word "Leaves" (25). In Puck Huneker's father's description of Whitman as "that shameless rascal" reads "that fellow" in IAP (26). The unmistakable sentence in Puck that follows Huneker's reference to the "third sex"- "We are permitted by a generous convention to speak of Jonathan and David, the Greeks, Verlaine, Oscar Wilde, or the psychopathic significance of Parsifal; yet the Whitman case you are supposed to ignore, despite the fact that in no literature has inverted frankness stalked with such proud bearing and beaming self-approval as through these pages" (8) - is omitted in IAP.

The number of errors perpetuated in $I A P$ is surprising and suggests that in his later years Huneker grew less careful and painstaking, perhaps because he was overwhelmed by the necessity of turning out journalistic copy and too busy to check his facts instead of relying on an increasingly shaky memory. The errors found in $I A P$ can be listed as follows:

1. He says the 1867 edition of Leaves was the "third, if I am not mistaken. ..."(22). It was actually the fourth.

2. He says his visit to Whitman occurred "some time after the Fourth of July, 1877 " (23). This is literally accurate but unless there was an unrecorded earlier visit, the entry in Whitman's notebook (now in the Library of Congress) indicates that it occurred in the spring of $1878 .{ }^{6}$

3. He says he visited Whitman "at his little house on Mickle Street" (23). In 1878 Whitman was not living on Mickle Street but on Stevens Street with his brother George; he did not move into the house he bought on Mickle Street until March 26, $1884 .^{7}$ 
4. He writes: "I doubt that [Whitman] ever drank spirits" (25). The poet did, not only champagne but "stronger spirits."

5. He writes: "Mr. Harlan, Secretary of the Interior when he dismissed Walt from his department because of Leaves, did not know about the Calamus section-I believe they were not incorporated until later ...." (25). The Calamus poems, of course, appeared in the third edition, published in 1860, five years before Whitman's dismissal.

6. He writes: "I remember a dinner given by the Whitman Society about twenty years ago at the St. Dennis Hotel. . . . The guest of honor was 'Pete' Doyle ...." (31). Huneker's dating of the event, which would place it in 1894 or 1895 , is inexact; it occurred on May $31,1898 .^{9}$

7. He writes: "Quite appropriately [Whitman's] dying word was le mot de Cambronne" ( 31 ; italics mine), namely "shit." This is his most curious error, and one wonders at his source. Horace Traubel, who was present when Whitman died, states that the poet's last word was the closely sounding "shift."

In his essay the down-to-earth Huneker underestimated Whitman's philosophy_-"fudge," he called it-and his mysticism, which he labeled a "muddled echo of New England Transcendentalism, itself a pale dilution of an outworn German idealism" $(28,29)$. Huneker's apparent distaste for Whitman's homosexuality, prescient though his recognition of it was, and his scorn toward those disciples who failed to recognize it or denied it or who, like Whitman himself, based their view of American democracy on it, caused him perhaps to overemphasize this aspect of Whitman. But in "A Visit to Walt Whitman" Huneker's criticism of Whitman's poetry is generally sound, despite his musician's dislike of free verse. The poems in "Children of Adam," he wrote,

leave me cold, despite their erotic vehemence; abuse of the vocative is not persuasive, their raptures are largely rhetorical. . . . [Whitman's] chief asset is an extraordinary sensitiveness to the sense of touch ... and an eye that records appearances, the surface of things, and registers in phrases of splendor the picturesque, yet seldom fuses matter and manner into a poetical synthesis. ... He contrives atmosphere with facility, and can achieve magical pictures of the sea and the "mad naked summer night." His early poem, "Walt Whitman," is for me his most spontaneous offering. He has at times the primal gift of the poet-ecstasy; but to attain it he often wades through shallow, ill-smelling sewers, scales arid hills, traverses dull drab levels where the slag covers rich ore, or plunges into subterrene pools of nocturnal abominations. . . . (27, 29-30)

His strictures notwithstanding, Huneker's concluding sentence underlines the main thrust of his view of Whitman and reveals a lingering admiration for Whitman's frankness on sex: "And he was a gay old pagan who never 
called a sin a sin when it was a pleasure." Despite its lamentable factual errors, Huneker's essay certainly holds a place of significance in the history of Whitman criticism.

\section{ARNOLD T. SCHWAB}

\section{NOTES}

1 See my biography, Fames Gibbons Huneker: Critic of the Seven Arts (Stanford, CA: Stanford University Press, 1963), and my articles, "James Huneker's Criticism of American Literature," American Literature 29 (March 1957), 66-67, and "James Huneker on Whitman: A Newly Discovered Essay," American Literature 38 (May, 1966) 208-218.

2 Fred Lewis Pattee, The New American Literature (New York: Century Co., 1930), 439.

3 Ivory Apes and Peacocks (New York: Charles Scribner's Sons, 1915), 28. In the "Raconteur," Huneker wrote, a little less explicitly, that Whitman, "despite his roaring masculinity, had a streak of the effeminate in him. All who knew his intimate side are aware of this. . . . Read the section called 'Calamus' in Leaves of Grass and wonder no longer. It is Greek with its curious antique profile and rank forbidden flavor" (Musical Courier 37 [July 12, 1898], 23-24).

4 Huneker is not among the critics whose essays are included in the selected bibliography in Richard H. Rupp's edition of Critics on Whitman: Readings in Literary Criticism (Coral Gables, FL: University of Miami Press, 1972), for example.

5 Scott Giantvalley notes there were "minor changes, including some deletions of homosexuality discussion," but he does not describe them (Walt Whitman, 1838-1939 [Boston: G. K. Hall, 1981], 247).

6 Huneker's name and a different, later Philadelphia address undated on a slip of paper are published in Whitman's Daybooks and Notebooks, ed. William White (New York: New York University Press, 1978), 1:175, but Huneker said in both Puck and $I A P$ that he never saw Whitman again in Camden, although earlier in the "Raconteur" he referred to "each visit [I] paid to Mickle street" (Musical Courier 33 [September 23, 1896], 19).

7 Jerome Loving, Walt Whitman: The Song of Himself (Berkeley: University of California Press, 1999), 347, 356, 428.

8 Loving, 473-474. See Horace Traubel, With Walt Whitman in Camden, vol. 8, ed. Jeanne Chapman and Robet MacIsaac (Oregon House, CA: W. L. Bentley, 1996), 261, 278.

9 New York Times (June 1, 1898), 7. Murray G. Martin mistakenly states that the event occurred in 1899 (“"Pete the Great': A Biography of Peter Doyle," Walt Whitman Quarterly Review 12 [Summer 1994], 43).

10 Horace Traubel, With Walt Whitman in Camden, vol. 9, ed. Jeanne Chapman and Robert MacIsaac (Oregon House, CA: W. L. Bentley, 1996), 598. Emory Holloway states that, according to Whitman's nurse Elizabeth Keller, his last words were "Warry, shift," as he asked his male nurse to change his position on the bed ("Whitman's Last Words," American Literature 24 [November 1952], 367). H. L. Mencken, graphically describing Huneker's variegated talk, refers to his quoting the "authentic last words of 
Whitman, gasped into poor Horace Traubel's solicitous ear, and too horrible, almost, to be remembered in a Christian land" ("Introduction," Essays by fames Huneker [New York: Charles Scribner's Sons, 1929], xiv). As for Whitman's use of the word "shit," one might adduce Ellen O'Connor Calder's statement that "no man ever lived who loathed coarseness and vulgarity in speech more than he" (quoted in David S. Reynolds, Walt Whitman's America: A Cultural Biography [New York: Alfred A. Knopf, 1995], 203). On the other hand, Traubel does record Whitman using the word.

\section{WALTER DE LA MARE AND WALT WHITMAN: A BIBLIOGRAPHICAL NOTE}

Scott Giantvalley, in his Walt Whitman, 1838-1939: A Reference Guide (Boston: G. K. Hall, 1981), cites the following essay under the year 1915: "[de la Mare, Walter.] 'Drum-Taps.' Times Literary Supplement (London) (1 April), 105-6" (item 31, p. 248). Giantvalley does not mention the reprinting of this essay in the Chatto \& Windus edition of Drum-Taps later in 1915. Joel Myerson, in Walt Whitman: A Descriptive Bibliography (Pittsburgh: University of Pittsburgh Press, 1993), indicates that the Chatto \& Windus Drum-Taps reprints the introductory essay from "the 1 April 1915 Times Literary Supplement [by Walter de la Mare]" (151). Giantvalley's and Myerson's brackets indicate that the TLS article, like its reprinting in the Chatto \& Windus Drum-Taps, was unsigned. There is no indication what source Giantvalley and Myerson used to identify de la Mare as the author.

Several years ago, I acquired from a London bookseller a copy of the Chatto \& Windus Drum-Taps, in which was tucked a typewritten letter written on London Times Literary Supplement stationery by Fay Hall, Editor's Secretary, to one L. A. Wallrich, Esq., Thomastown House, Edenderry, Co. Offaly, Ireland:

\section{March 1965.}

Dear Mr. Wallrich,

Thank you for your letter of 8 March.

In the circumstances there is no objection to your knowing that the writer of the article on Drum-Taps was Walter de la Mare.

Yours sincerely,

Fay Hall

Editor's Secretary

This letter provides definitive evidence that de la Mare (1873-1956) was indeed the author of the essay "Drum-Taps" and that, as late as 1965, the identity of the author was still something of a mystery. 